\title{
In vitro protein synthesis capacities in a cold stenothermal and a temperate eurythermal pectinid
}

Accepted: 13 June 2003 / Published online: 6 August 2003

(C) Springer-Verlag 2003

\begin{abstract}
The translational system was isolated from the gills of the Antarctic scallop Adamussium colbecki (Smith) and the European scallop Aequipecten opercularis (Linnaeus) for in vitro protein synthesis capacities ( $\mu \mathrm{g}$ protein $\mathrm{mg} \mathrm{FW}^{-1} \mathrm{day}^{-1}$ ) and the translational capacities of RNA ( $\mathrm{k}_{\mathrm{RNA}}$ in vitro $\mathrm{mg}$ protein $\mathrm{mg} \mathrm{RNA}^{-1}$ day $^{-1}$ ). In vitro protein synthesis capacity in the coldadapted pectinid at $0{ }^{\circ} \mathrm{C}$ was similar to the one found in the temperate scallop at $25^{\circ} \mathrm{C}$. These findings might reflect cold compensated rates in Adamussium colbecki, partly explainable by high tissue levels of RNA. Coldcompensated in vitro protein synthesis capacities may further result from increments in the translational capacity of RNA. The thermal sensitivity of the translation machinery was slightly different in the two species, with significantly lower levels of Arrhenius activation energies $\mathrm{E}_{\mathrm{a}}$ and $\mathrm{Q}_{10}$ in Adamussium colbecki in the temperature range $0-15{ }^{\circ} \mathrm{C}$. Reduced protein synthesis and translational capacities were found in vitro in gills of long-term aquarium-maintained Adamussium colbecki and were accounted for by a loss of protein synthesis machinery, i.e. a reduction in RNA levels, as well as a decrease in the amount of protein synthesized per milligram of RNA (RNA translational capacity, $\mathrm{k}_{\mathrm{RNA}}$ in vitro). Such changes may involve food uptake or mirror metabolic depression strategies, like those occurring during winter. Consequences of high in vitro RNA translational capacities found in the permanently coldadapted species are discussed in the context of seasonal food availability and growth rates at high latitudes.
\end{abstract}

Communicated by G. Heldmaier

D. Storch · O. Heilmayer · H.-O. Pörtner $(\bowtie)$

Benthic Systems, Ecophysiology and Ecotoxicology,

Alfred Wegener Institute for Polar and Marine Research,

Columbusstraße, D-27568 Bremerhaven, Germany

E-mail: hpoertner@awi-bremerhaven.de

Fax: + 49-471-48311149

I. Hardewig

Leibniz-Institute of Freshwater Ecology and Inland Fisheries, Müggelseedamm 301, 12561 Berlin, Germany
Keywords Protein synthesis - Translational capacity · Translational efficiency $\cdot$ Cold adaptation $\cdot$ Pectinids

Abbreviations $D P M$ disintegrations per minute $\cdot D T T$ dithiothreitol $\cdot E_{a}$ Arrhenius activation energy $\cdot k_{s}$ fractional protein synthesis rate $\cdot k_{R N A}$ in vivo translational efficiency $\cdot k_{R N A}$ in vitro translational capacity $\cdot P C A$ perchloric acid $\cdot$ Phe phenylalanine $\cdot P L A$ phospho-L-arginine $\cdot P S U$ practical salinity units $\cdot R N A$ se ribonuclease $\cdot T C A$ trichloroacetic acid

\section{Introduction}

Psychrophiles have successfully colonized the yearround cold waters of Antarctica and are able to grow efficiently at sub-zero temperatures. Nonetheless, mean annual growth rates are low compared to temperate ectotherms (Brey and Clarke 1993). A vast array of structural and physiological adjustments is required to counteract the reduction in chemical reaction rates due to low temperature and to ensure matching of the processes of energy production and consumption including those of growth, muscular activity and reproduction. One major component of basal processes is protein turnover (Hawkins 1991). Protein synthesis balances routine protein degradation with a significant net production during growth and, otherwise, comprises a significant fraction of maintenance metabolism in terms of protein turnover. Protein synthesis is energetically expensive, regardless of temperature (Storch and Pörtner 2003). Thus, the regulation of protein turnover and synthesis rates is of utmost importance especially in cold-adapted ectotherms at low rates of oxygen consumption and, consequently, low energy turnover.

Whole body protein synthesis has been shown to reach similar maximum rates in cold-adapted species compared to their temperate congeners (Whiteley et al. 1996; Marsh et al. 2001; Fraser et al. 2002). Whole body 
protein synthesis is a summation of synthesis rates in various tissues, which differ widely in protein turnover and metabolic rate. In fish and a few invertebrates examined to date, gills are among those tissues with very high turnover rates and low protein retention efficiencies, whereas muscle is characterized by low turnover rates and high protein retention efficiencies (Houlihan et al. 1986; Houlihan 1991).

Recent work suggests that ectotherms living at low temperatures maintain considerably elevated tissue RNA:protein ratios due to increased RNA levels. Such high ratios in cold-adapted ectotherms have been interpreted to compensate for a cold-induced reduction in RNA translational efficiency in vivo ( $\mathrm{k}_{\mathrm{RNA}}$ in vivo (Whiteley et al. 1996; Robertson et al. 2001; Fraser et al. 2002). In Antarctic sea urchin embryos, elevated levels of mRNA and whole-cell RNA were suggested to enable their high protein turnover rates, equivalent to those in temperate zone sea urchin embryos (Marsh et al. 2001). These suggestions also imply that in vivo translational efficiency, defined as in vivo protein synthesis per unit RNA ( $\mathrm{k}_{\mathrm{RNA}}$ in vivo), is reduced because of the temperature-induced reduction in individual biochemical processes involved in protein synthesis. In this context, it is of interest whether synthesis and maintenance of higher RNA levels to counteract the negative effect of cold temperatures on translational activity result in higher costs of protein synthesis. Alternatively, an increased RNA content in cold-adapted ectotherms may just be the result of low RNA turnover rates. In any case, a cold-adapted RNA translation apparatus with enhanced catalytic efficiencies would support increased costefficiency, however, it is unclear whether such a coldcompensated translation system on top of increased RNA levels exists.

In the present study we isolated the translational system from the gills of the Antarctic scallop Adamussium colbecki (Smith) under different nutritional conditions, and from the European scallop Aequipecten opercularis (Linnaeus). Our aim was to determine the translational capacity ( $\mathrm{k}_{\mathrm{RNA}}$ in vitro $)$ of the protein synthesis machineries of marine invertebrates adapted to different ambient temperatures, using an optimized in vitro cell-free system simulating physiological conditions (Storch and Pörtner 2003). The in vitro system enabled us to study the effect of temperature and nutritional status on protein synthesis capacities under conditions of unrestricted energy availability and amino acid supply in the assay. The measurement of in vitro amino acid incorporation is a far more sensitive and immediate indicator for RNA translational capacity than the RNA:protein ratio measured in vivo (Lied et al. 1985; Houlihan 1991). For maximum rates and high signal-tonoise ratios, the translational system was isolated from the gills. To our knowledge, this is the first quantitative study to investigate the RNA translational capacities of the protein synthesis machinery in vitro and to contrast the respective findings in a permanently cold-adapted ectotherm and a temperate ectotherm.
For this study, we chose two species from the pectinid family, the cold stenothermal Adamussium colbecki from the Antarctic Ross Sea and the temperate eurythermal Aequipecten opercularis from the British channel. Both Adamussium colbecki and Aequipecten opercularis represent key species in their respective habitats. Adamussium colbecki experiences constant annual temperatures ranging between $-1.8^{\circ} \mathrm{C}$ and $2.5^{\circ} \mathrm{C}$, whereas Aequipecten opercularis covers a broader temperature range of between $8{ }^{\circ} \mathrm{C}$ and $24{ }^{\circ} \mathrm{C}$. Other temperate species (e.g. Pecten maximus) are more closely related to Adamussium colbecki (Canapa et al. 2000); however, the mode of life of Adamussium colbecki resembles more closely that of Aequipecten opercularis (epibenthic filter feeding, spontaneous and escape activity cycles), albeit at significantly lower levels of energy expenditure in Adamussium colbecki (Heilmayer and Brey 2003; Heilmayer et al. 2004). For cellular design and functional capacity, the similarity in lifestyle in different environments appears as crucial for such comparisons as close phylogenetic relationship, especially in the light of 20 million years of progressive cooling of Antarctic waters and the long standing geographic isolation of Antarctic species (Bailey et al. 2003). Accordingly, different protein synthesis capacities in species from Antarctic and temperate latitudes may reflect general cellular design constraints in the permanent cold (Pörtner 2002).

Our results demonstrate that translation capacity in the cold-adapted pectinid at $0{ }^{\circ} \mathrm{C}$ exhibits cold compensation. The in vitro RNA translational capacities and overall protein synthesis capacities measured in this study are discussed in the context of energy turnover and the nutritional state of ectotherms inhabiting different latitudes and temperature regimes.

\section{Materials and methods}

\section{Animals}

Aequipecten opercularis of $4.30 \pm 0.15 \mathrm{~cm}$ shell length and $4.28 \pm 0.13 \mathrm{~cm}$ height were provided by the "Station Biologique de Roscoff". They were caught at $80-\mathrm{m}$ water depths by dredging around Roscoff (France) in October 1999. Animals were kept in oxygenated, cooled seawater and returned by car to the Alfred Wegener Institute (AWI). There they were kept in well-aerated, re-circulated seawater at $10 \pm 1{ }^{\circ} \mathrm{C}$ and 34 practical salinity units (PSU) for at least 6 days prior to experimentation. Adamussium colbecki of $4.42 \pm 0.21 \mathrm{~cm}$ shell length and $4.65 \pm 0.17 \mathrm{~cm}$ height were collected by dredging from 50-80-m water depth near Terra Nova Bay (Antarctica) in February 2000. They were maintained in running seawater aquaria at $0.0 \pm 0.5^{\circ} \mathrm{C}$ and $34 \mathrm{PSU}$ at Terra Nova Bay station for 6 days prior to experimentation. Some of the animals were returned by plane to the AWI in insulated cooling boxes and plastic bags filled with oxygenated cold seawater and a layer of pure oxygen. During the whole transport the boxes were kept in an airfreight container at a constant temperature of $0 \pm 0.5^{\circ} \mathrm{C}$. At the Institute animals were kept in well-aerated seawater at $0.0 \pm 0.5^{\circ} \mathrm{C}$ and 34 PSU and were fed twice a week with dissolved plankton tablets $\left(0.01 \mathrm{~g} \mathrm{C} \mathrm{m}^{2}\right.$ ind $^{-1}$ per meal, HOBBY, Dohse Aquaristik). After 6 months aquarium maintenance, the same experiments were conducted as for freshly captured Adamussium colbecki and Aequipecten opercularis. 
Preparation of gill lysates

The preparation of lysates from the gills of Aequipecten opercularis and of Adamussium colbecki followed the same procedure as detailed by Storch and Pörtner (2003) and will only briefly be outlined here. Gills of two animals were pooled to provide enough tissue for all measurements. Half of the combined tissue mass was freezeclamped in liquid $\mathrm{N}_{2}$ by means of a pre-cooled Wollenberger clamp (Wollenberger et al. 1960) for later examination of RNA and protein contents. The other half was immediately used for the preparation of the cell-free protein-synthesis system. Gill tissue was homogenized with a loosely fitting $2-\mathrm{ml}$ glass homogenizer in 1 volume of ice-cold extraction buffer [containing $100 \mathrm{mM}$ Hepes, $880 \mathrm{mM}$ sucrose, $120 \mathrm{mM}$ K-acetate, $10 \mathrm{mM}$ Mg-acetate, $7 \mathrm{mM}$ 2-mercaptoethanol, $30 \mathrm{mM}$ dithiothreitol (DTT), adjusted to $\mathrm{pH} 7.13$ at $\left.25^{\circ} \mathrm{C}\right]$. The homogenate was centrifuged at $16,000 \mathrm{~g}$ for $30 \mathrm{~min}$ at $0{ }^{\circ} \mathrm{C}$ and the resulting post-mitochondrial supernatant was used as the lysate, which was kept on ice until the start of the in vitro translation assays to minimize destruction of RNA by endogenous ribonuclease (RNAse). Aliquots of the lysates were frozen in liquid nitrogen for later determination of RNA and endogenous phenylalanine (Phe).

\section{Cell-free in vitro translation assays}

Protein synthesis rates were determined in vitro at four different temperatures. Lysates prepared from gills of recently captured Adamussium colbecki $\left(0{ }^{\circ} \mathrm{C}, 5^{\circ} \mathrm{C}, 10{ }^{\circ} \mathrm{C}, 15^{\circ} \mathrm{C}\right)$ were measured at TNB station in Antarctica. Lysates prepared from gills of freshly captured Aequipecten opercularis $\left(0^{\circ} \mathrm{C}, 5^{\circ} \mathrm{C}, 15^{\circ} \mathrm{C}, 25^{\circ} \mathrm{C}\right)$ and long-term maintained Adamussium colbecki $\left(0^{\circ} \mathrm{C}, 5^{\circ} \mathrm{C}, 15^{\circ} \mathrm{C}\right)$ were analysed at the AWI.

For measurements of the capacity of protein synthesis, translation assays were conducted under optimized, physiological conditions as described previously (Storch and Pörtner 2003). Incorporation of $\left[2,3,4,5,6-{ }^{3} \mathrm{H}\right]$ Phe into protein was measured as a function of time in $19-\mu \mathrm{l}$ samples from an incubation medium containing $30 \mu \mathrm{l}$ lysate $150 \mu^{-1}$ and, on top of the ionic composition of the lysate, $100 \mathrm{mM}$ Hepes buffer (sodium salt, adjusted to $\mathrm{pH} 7.13$ at $25^{\circ} \mathrm{C}$ ), $85 \mathrm{mM}$ taurine, $150 \mathrm{mM}$ glycine, $120 \mathrm{mM}$ potassium, $5 \mathrm{mM}$ DTT, $0.2 \mathrm{mM}$ spermidine, all amino acids except Phe at $0.1 \mathrm{mM}, 8 \mu \mathrm{M}$ Phe (including $60 \mu \mathrm{Ci}$ $\left[2,3,4,5,6-{ }^{3} \mathrm{H}\right]$ Phe, Amersham, $\left.116 \mathrm{Ci} \mathrm{mmol}^{-1}, 1 \mathrm{mCi}=37 \mathrm{MBq}\right)$, 100 units RNasin Ribonuclease Inhibitor (Promega), $1 \mathrm{mM}$ ATP, $0.5 \mathrm{mM}$ GTP and for ATP regeneration $15 \mathrm{mM}$ phospho-l-arginine (PLA) and 4.9 units arginine kinase to avoid a limitation of energy supply. Before starting the translation assay with $30 \mu \mathrm{l}$ lysate, the reaction mixture was pre-incubated for $5 \mathrm{~min}$ in a water bath set to the experimental temperature of $0{ }^{\circ} \mathrm{C}, 5{ }^{\circ} \mathrm{C}$, $10{ }^{\circ} \mathrm{C}$ or $15^{\circ} \mathrm{C}$ for freshly collected and long-term maintained Adamussium colbecki and of $0{ }^{\circ} \mathrm{C}, 5{ }^{\circ} \mathrm{C}, 15^{\circ} \mathrm{C}$ or $25^{\circ} \mathrm{C}$ for Aequipecten opercularis. After the addition of lysate, the assay was quickly subdivided into aliquots of $20 \mu \mathrm{l}$ and returned to the water bath set to the experimental temperature. Reactions were terminated by $2 \mu \mathrm{l}$ pancreatic RNAse $\left(25\right.$ units $\left.\mathrm{ml}^{-1}\right)$, followed by an additional $5 \mathrm{~min}$ of incubation at $15{ }^{\circ} \mathrm{C}$ for Adamussium colbecki and $25{ }^{\circ} \mathrm{C}$ for Aequipecten opercularis to ensure a quick halt of the protein synthesis. Subsequently, 19- $\mu$ l samples were pipetted onto Phe-saturated, semi-wet Whatman GF/C filters. Filters were immersed in ice-cold $10 \%$ trichloroacetic acid (TCA), containing $5 \mathrm{mM}$ Phe, then washed once in $10 \%$ and twice in $5 \%$ ice-cold TCA. After a final rinse in $95 \%$ ethanol, the filters were allowed to dry in air before dissolving them in $5 \mathrm{ml}$ scintillation cocktail (Packard, 57\% tritium counting efficiency). Radioactivity in the precipitated protein was determined by liquid scintillation counting. A sham control, which permanently contained pancreatic RNAse to prevent protein synthesis, was used to correct for background due to non-specific binding of $\left[2,3,4,5,6-{ }^{3} \mathrm{H}\right]$ Phe to components of the lysate. Results were expressed as $\left[2,3,4,5,6-{ }^{3} \mathrm{H}\right]$ Phe incorporated into TCA-precipitable protein [DPM $19 \mu \mathrm{l}$ assay $^{-1}$.
Analytical methods

Total RNA in lysates was hydrolysed by alkaline exposure according to the Schmidt-Tannhauser procedure and quantified by the dual-wavelength procedure of Munro and Fleck (1966). For relating RNA concentration to absorbance at these two wavelengths, the modified, more suitable formula, RNA $(\mu \mathrm{g}$ $\left.\mathrm{ml}^{-1}\right)=32.9 \times \mathrm{A} 260-6.11 \times \mathrm{A} 232$, was used as suggested by Ashford and Pain (1986). The free, endogenous Phe levels in lysates were measured by RP-HPLC in the lab "Dr. Haase-Aschoff" (Bad Kreuznach, Germany). For the determination of RNA and protein contents of gill, muscle, mantle and gonad, tissues were ground to a fine, homogeneous powder under liquid nitrogen using a pre-cooled mortar and pestle. Two $100-\mathrm{mg}$ sub-samples of the resultant powder were homogenized in ice-cold $0.2 \mathrm{M}$ perchloric acid (PCA). Homogenates were centrifuged at $16,000 \mathrm{~g}$ for $1 \mathrm{~min}$ at $0{ }^{\circ} \mathrm{C}$ and the remaining precipitate was washed twice in $0.2 \mathrm{M}$ PCA.

Subsequently, the pellet was resuspended in $0.3 \mathrm{M} \mathrm{NaOH}$ and incubated for $1 \mathrm{~h}$ at $37^{\circ} \mathrm{C}$. Sub-samples $(15 \mu \mathrm{l})$ were taken for the determination of protein levels using a modified Lowry technique with bovine serum albumin as a standard (Sigma procedure no. P5656). Protein and DNA were then precipitated from the remaining alkali digest by the addition of ice-cold $20 \%$ PCA, and after centrifugation the resultant acid-soluble fraction was removed for the estimation of RNA levels by ultraviolet absorption at $232 \mathrm{~nm}$ and $260 \mathrm{~nm}$ as described above.

\section{Derived parameters and statistics}

Protein synthesis rates at the different experimental temperatures were determined using the initial, linear intercept of the timedependent $\left[2,3,4,5,6-{ }^{3} \mathrm{H}\right]$ Phe incorporation curves. In order to compare in vitro incorporation rates in this study to in vivo and in vitro protein synthesis rates reported in the literature, protein synthesis rates were converted from disintegrations per minute (DPM; $19 \mu \mathrm{l}$ assay $\left.^{-1} \min ^{-1}\right)$ via nanomoles Phe $(19 \mu \mathrm{l}$ assay $^{-1}$ min $^{-1}$ ) into micrograms protein per fresh weight per day. Therefore, the specific radioactivity, expressed as $\mathrm{Bq}$ pmol $\mathrm{Phe}^{-1}$ (1 $\mathrm{DPM}=1 / 60 \mathrm{~Bq}$ ), of each assay was calculated from the amount of added radioactive and non-radioactive Phe in the assay plus the measured endogenous free Phe of the lysates. Based on the total amino acid composition of gill protein, measured previously (Storch and Pörtner 2003), the ratio of the concentration of each amino acid to the Phe level in tissue protein from gills of both species was used to calculate the relationship between nanomoles of Phe incorporated and micrograms of protein synthesized. It was assumed that the ratios of amino acid over Phe levels in the protein remained unchanged between gills of freshly captured and longterm maintained Adamussium colbecki. The molecular weights of the respective amino acids were used in the conversion.

For comparison with in vivo data taken from the literature, protein synthesis rates were converted into fractional protein synthesis rates as usually determined in vivo (see Discussion). Fractional protein synthesis rates of gill tissues which indicate protein turnover $\left(\mathrm{k}_{\mathrm{s}}\right.$; expressed as a percentage of the total gill protein synthesized per day), were calculated using the following equation:

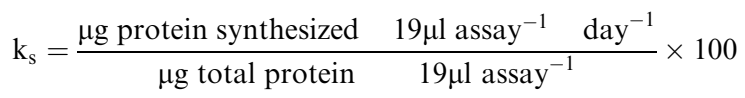

where $\mu \mathrm{g}$ total protein is the protein content of the tissue used to prepare the lysate.

The maximum translational capacity of RNA determined in vitro ( $\mathrm{k}_{\mathrm{RNA}}$ in vitro expressed as milligrams protein per milligrams RNA per day) is comparable to the translational efficiency of RNA in vivo ( $\mathrm{k}_{\mathrm{RNA}}$ in vivo, also expressed as mg protein per mg RNA and day) and was calculated using the equation:

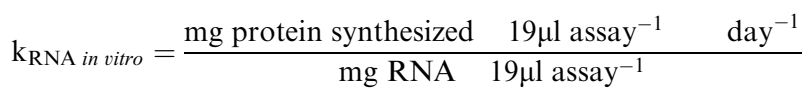


The levels of Arrhenius activation energy $\left(E_{a}\right)$ and $Q_{10}$ were determined from an Arrhenius plot, i.e. $\log \mathrm{V}_{\text {protein synthesis }}$ versus $1 / T\left(\mathrm{~K}^{-1}\right)$. $\mathrm{E}_{\mathrm{a}}$ values were expressed as $\mathrm{E}_{\mathrm{a}}\left(\mathrm{kJ} \mathrm{mol}^{-1}\right)=-\mathrm{R}^{*} \mathrm{~m} * 1000$ (modified by Segel 1976) where $R$ is the gas constant $\left(\mathrm{J} \mathrm{mol}^{-1} \mathrm{~K}^{-1}\right)$ and $m$ is the slope of the Arrhenius plot.

All data are expressed as means \pm standard deviation $(\overline{\mathrm{X}} \pm \mathrm{SD})$ unless stated otherwise. Numbers $(n)$ of determinations are given in figure legends. Prior to analysis, assumptions of normal distribution of the studied variables and homogeneity of variances were tested by use of Sigmastat. If any of the assumptions was violated, the data were transformed by $(1 / \mathrm{x})$ transformation, which resulted in significantly improved normality and homogeneity of variances. Statistical differences at the 5\% level were tested using analysis of variance (ANOVA) followed by the Student-Newman-Keuls post hoc test.

\section{Results}

Characterization of gill lysates

RNA contents and endogenous Phe levels in lysates of fresh captured Adamussium colbecki $(0.883 \pm 0.037 \mathrm{mg}$ RNA ml ${ }^{-1} ; 0.292 \pm 0.046 \mathrm{mM}$ Phe) were significantly higher than in lysates of freshly captured Aequipecten opercularis $\left(0.468 \pm 0.013 \mathrm{mg}\right.$ RNA $\mathrm{ml}^{-1} ; 0.111 \pm$ $0.009 \mathrm{mM}$ Phe). This indicates higher levels of RNA and endogenous Phe in the Antarctic species. RNA content in lysates of both species was $79 \pm 9 \%$ of that observed in the tissue, which was $2.30 \pm 0.13 \mu \mathrm{g} \mathrm{mg}^{-1}$ gill tissue in Adamussium colbecki and $1.17 \pm 0.17 \mu \mathrm{g} \mathrm{mg}^{-1}$ gill tissue in Aequipecten opercularis. Thus it appears that there was a $20 \%$ loss of ribosomes during the preparation of the gill lysates.

During long-term aquarium maintenance the RNA content as well as the endogenous free Phe levels of Adamussium colbecki gills had decreased markedly $\left(0.599 \pm 0.062 \mathrm{mg}\right.$ RNA ml ${ }^{-1} ; 0.058 \pm 0.015 \mathrm{mM}$ Phe $)$ after 6 months compared to freshly captured Adamussium colbecki. RNA contents declined to values still significantly higher compared to the RNA content in gills of Aequipecten opercularis, whereas Phe fell significantly below values measured in Aequipecten opercularis. These findings show the large variability of RNA and Phe contents in the gill tissue of Adamussium colbecki under different physiological conditions.

\section{Characteristics of Phe incorporation}

Phe incorporation into protein requires functioning of the complete protein synthesis machinery of the cell. The system used here mimics the buffering, osmotic and ionic properties of gill tissue. By using the post-mitochondrial supernatant in an optimized cell-free system (Storch and Pörtner 2003), the maximum protein synthesis rates and, thus, the protein synthesis capacity of gill lysates of both species can be studied under identical physiological conditions.

Figure 1 shows the time course for incorporation of $\left[2,3,4,5,6{ }^{3} \mathrm{H}\right]$ Phe into TCA-precipitable material at

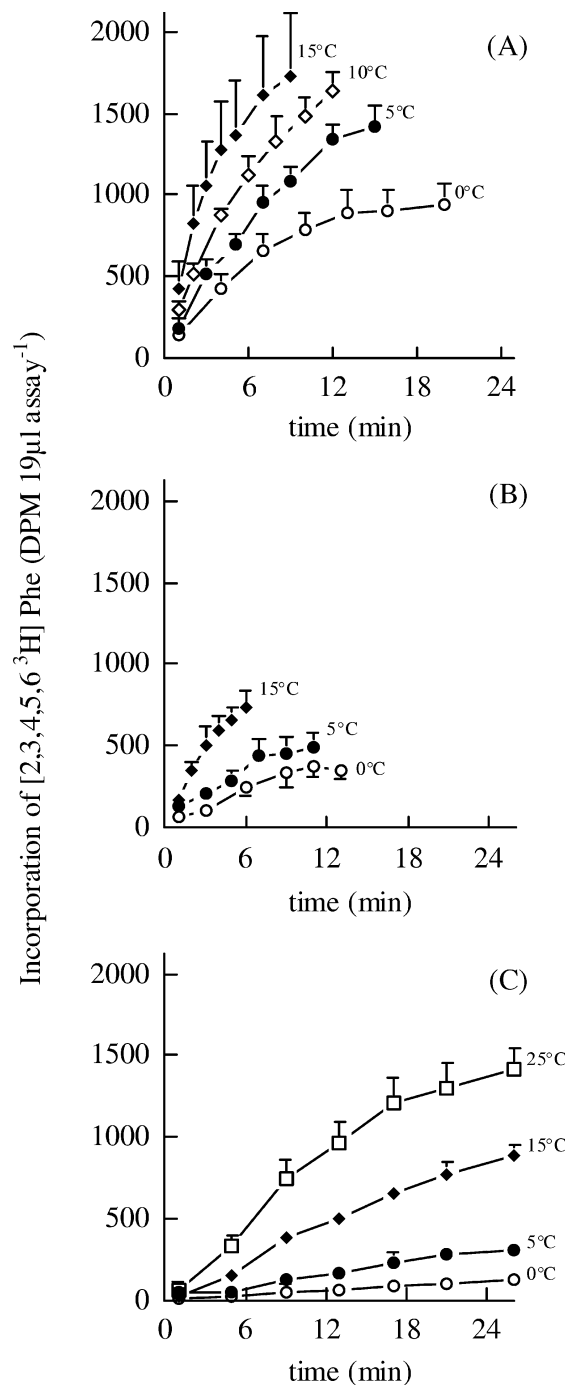

Fig. 1A-C Time course of incorporation of $\left[2,3,4,5,6-{ }^{3} \mathrm{H}\right]$ Phenylalanine $(P h e)$ into trichloroacetic acid-precipitable protein at different temperatures by cell-free lysates prepared from gills of freshly captured Adamussium colbecki (A), of long-term maintained Adamussium colbecki (B) and of Aequipecten opercularis $(\mathbf{C}) .0{ }^{\circ} \mathrm{C}$ : unfilled circles; $5{ }^{\circ} \mathrm{C}$ : filled circles; $10^{\circ} \mathrm{C}$ : unfilled rhombuses; $15{ }^{\circ} \mathrm{C}$ : filled rhombuses; $25^{\circ} \mathrm{C}$ : unfilled squares. Data points are means $\pm \operatorname{SE}(n=6 \mathrm{~A}, \mathbf{C} ; n=4 \mathbf{B})$

different temperatures by lysates prepared from freshly captured and long-term maintained Adamussium colbecki (Fig. 1A, B) and lysates prepared from Aequipecten opercularis (Fig. 1C). At all measured temperatures lysates prepared from both species exhibited the same characteristic time course of in vitro translation: a linear period of incorporation was followed by a progressive decrease of reaction velocity and approached completion in an asymptotic manner. There was a higher incorporation of Phe into protein at higher temperatures combined with an earlier slowing of the reaction. Short periods of linear incorporation in lysates are typical when compared to other non-reticulocyte cell-free systems (Hofmann and Hand 1994; Kim and Swartz 2000). Lysates prepared from freshly collected and long-term 
Table 1 Characteristics of cell-free lysates prepared from gills of freshly captured Aequipecten opercularis and Adamussium colbecki (f) and from gills of $A$. colbecki long term maintained in the aquarium (m). All values are means $\pm \mathrm{SD}$. (Phe phenylalanine)

\begin{tabular}{llll}
\hline Tissue & Species & $\begin{array}{l}\text { Total RNA } \\
\left(\mathrm{mg} \mathrm{ml}^{-1}\right)\end{array}$ & $\begin{array}{l}\text { Free Phe } \\
(\mathrm{mM})\end{array}$ \\
\hline Gill & Aequipecten opercularis & $0.47 \pm 0.03(n=6)$ & $0.11 \pm 0.02(n=5)$ \\
& Adamussium colbecki $(\mathrm{f})$ & $0.88 \pm 0.09(n=6)$ & $0.24 \pm 0.06(n=5)$ \\
& A. colbecki $(\mathrm{m})$ & $0.60 \pm 0.06(n=4)$ & $0.06 \pm 0.02(n=4)$ \\
\hline
\end{tabular}

maintained Adamussium colbecki exhibited constant rates of incorporation for the first 6-12 min depending on experimental temperature. However, a severe reduction of Phe incorporation velocity was observed in lysates prepared from long-term maintained Adamussium colbecki when compared to lysates of fresh animals. In contrast, Phe incorporation by lysates from Aequipecten opercularis displayed linear incorporation for longer periods. At $0{ }^{\circ} \mathrm{C}, 5{ }^{\circ} \mathrm{C}$ and $15^{\circ} \mathrm{C}$ incorporation remained constant for $20-26 \mathrm{~min}$ and at $25^{\circ} \mathrm{C}$ for about $17 \mathrm{~min}$, followed by a progressive reduction.

In vitro protein synthesis and RNA translational capacity

Protein synthesis capacities and RNA translational capacities at different temperatures were calculated from initial Phe incorporation rates according to Fig. 1, adopting Phe and RNA concentrations compiled in Table 1. In vitro protein synthesis capacity in gill lysates increased significantly with temperature (Fig. 2A). Within the temperature range $0-15^{\circ} \mathrm{C}$, protein synthesis capacities increased with identical $\mathrm{Q}_{10}$ in freshly captured Adamussium colbecki $\left(\mathrm{Q}_{10}=2.6 \pm 0.5\right)$ and longterm maintained Adamussium colbecki $\left(\mathrm{Q}_{10}=2.2 \pm 0.3\right)$, whereas the temperature dependency was significantly higher in Aequipecten opercularis $\left(\mathrm{Q}_{10}=3.4 \pm 0.6\right.$ between $0{ }^{\circ} \mathrm{C}$ and $15{ }^{\circ} \mathrm{C}$ ). Accordingly, activation energies of protein synthesis were significantly higher in Aequipecten opercularis than in freshly captured $A d a$ mussium colbecki $\left(\mathrm{E}_{\mathrm{a}}=78.5 \pm 9.8 \mathrm{~kJ} \mathrm{~mol}^{-1}\right.$ versus $\mathrm{E}_{\mathrm{a}}=62.9 \pm 11.3 \mathrm{~kJ} \mathrm{~mol}^{-1}$ ), whereas 6-month aquariummaintained Adamussium colbecki $\left(\mathrm{E}_{\mathrm{a}}=49.5 \pm 9.3\right.$ $\mathrm{kJ} \mathrm{mol}^{-1}$ ) displayed significantly reduced $\mathrm{E}_{\mathrm{a}}$ for in vitro protein synthesis.

Between $0{ }^{\circ} \mathrm{C}$ and $15{ }^{\circ} \mathrm{C}$, the overall protein synthesis capacity was significantly higher in both freshly captured and long-term maintained Adamussium colbecki, compared to Aequipecten opercularis. The Aequipecten cellfree system displayed a very low rate of protein synthesis at $0^{\circ} \mathrm{C}\left(0.6 \pm 0.1 \mu \mathrm{g}\right.$ protein $\mathrm{mg}^{-1} \mathrm{FW}$ day $\left.^{-1}\right)$ when compared to the 18-fold higher protein synthesis capacity in freshly captured Adamussium colbecki at $0{ }^{\circ} \mathrm{C}\left(10.4 \pm 2.7 \mu \mathrm{g}\right.$ protein $\left.\mathrm{mg}^{-1} \mathrm{FW} \mathrm{day}{ }^{-1}\right)$, and the rate in Aequipecten was still 4.6-fold lower compared to 6-month aquarium-maintained Adamussium colbecki at $0{ }^{\circ} \mathrm{C}\left(2.7 \pm 1.0 \mu \mathrm{g}\right.$ protein $\mathrm{mg}^{-1} \mathrm{FW}$ day $\left.^{-1}\right)$.

At the respective habitat temperatures, protein synthesis capacities were still significantly lower in
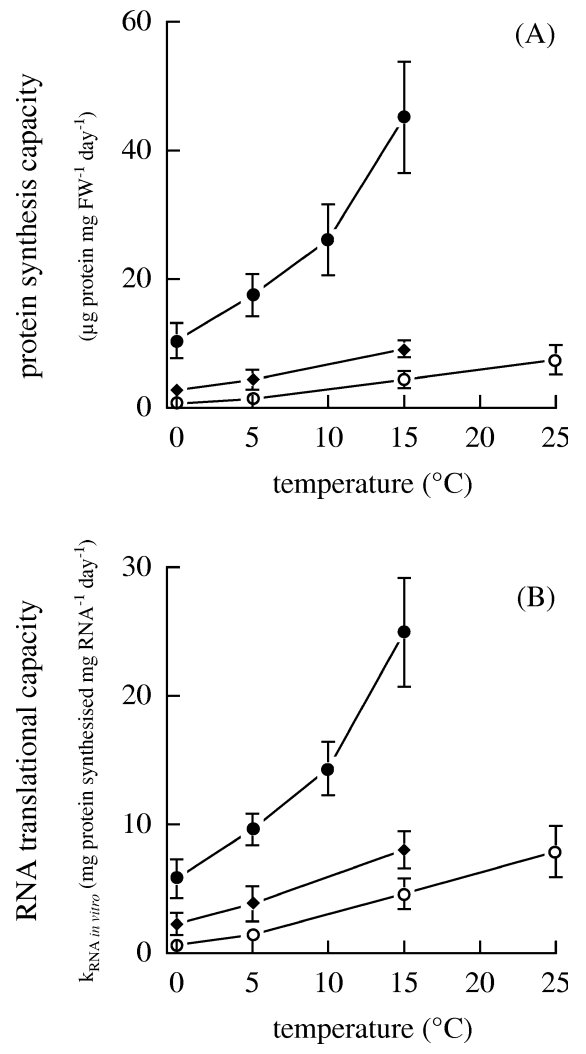

Fig. 2A-B Temperature-dependent in vitro protein synthesis capacities (A) and RNA translational capacities $\left(k_{R N A}\right.$ in vitro; $\left.;\right)$. filled circles: freshly captured Adamussium colbecki, filled rhombuses: long-term aquarium-maintained Adamussium colbecki, unfilled circles: Aequipecten opercularis. Data points are means \pm SD (freshly captured Adamussium colbecki and Aequipecten opercularis: $n=6$; long-term maintained Adamussium colbeck $i$ $n=4)$

Aequipecten opercularis measured at $5{ }^{\circ} \mathrm{C}$ and $15^{\circ} \mathrm{C}$ than in freshly captured Adamussium colbecki at $0{ }^{\circ} \mathrm{C}$. Only when close to the upper temperature limit of $25^{\circ} \mathrm{C}$, was protein synthesis capacity in the gills of Aequipecten opercularis the same as in gills of Adamussium colbecki at $0{ }^{\circ} \mathrm{C}$. Long-term aquarium-maintained Adamussium colbecki analysed at $0{ }^{\circ} \mathrm{C}$ still displayed rates within the same range as in Aequipecten opercularis measured at $15{ }^{\circ} \mathrm{C}$.

The 18-fold higher in vitro protein synthesis capacities of Adamussium colbecki at $0{ }^{\circ} \mathrm{C}$ can mainly be explained by the nine-fold higher RNA translational capacity (Fig. 2B). The remaining discrepancy can be attributed to the two-fold difference in RNA contents in the lysate (Table 1). Thus, both high RNA contents and 
high RNA translational capacities supported the high protein synthesis capacities observed in gill lysates of freshly captured Adamussium colbecki. The reduced RNA contents in gill lysates of long-term aquariummaintained Adamussium colbecki as well as their reduced RNA translational capacity went hand in hand to support a markedly reduced protein synthesis capacity. Low protein synthesis capacities in gill lysates of Aequipecten opercularis were also related to even lower RNA contents and RNA translational capacities than in longterm maintained Adamussium colbecki.

RNA, protein and RNA:protein ratio

RNA and protein concentrations as well as RNA:protein ratios, were measured in three other tissues for an evaluation of protein synthesis capacities (Fig. 3). In fact all tissues analysed in freshly captured Adamussium colbecki showed significantly higher RNA:protein ratios
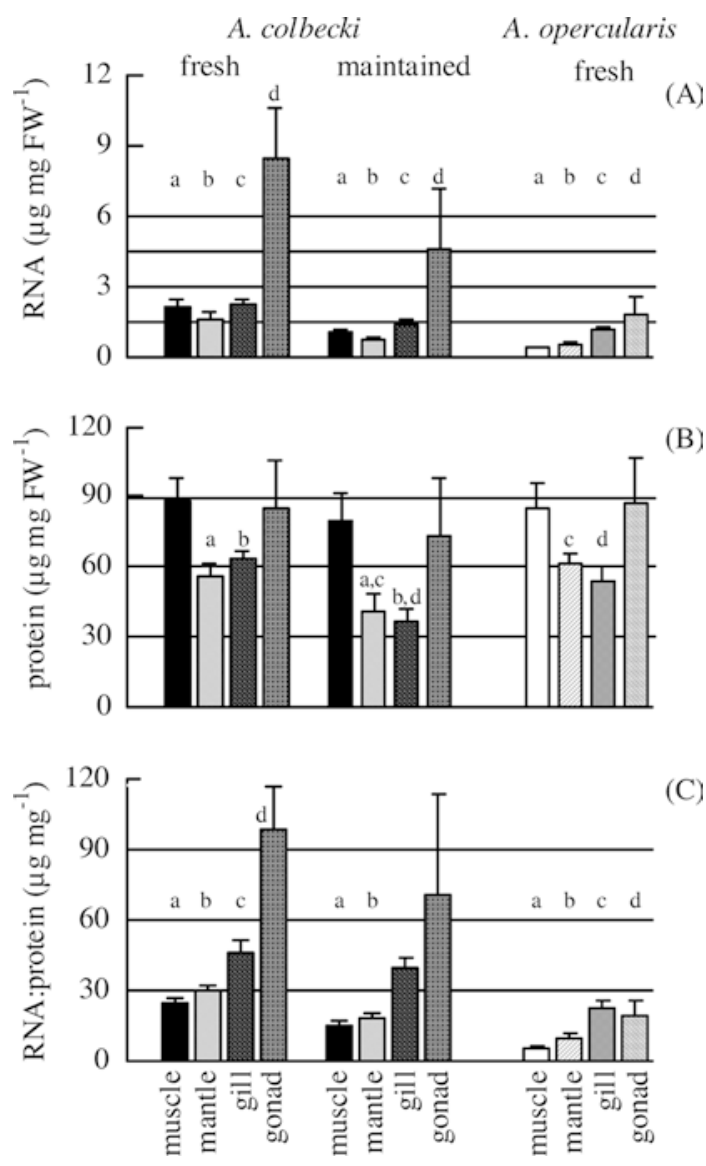

Fig. 3A-C RNA (A), protein (B) concentrations and RNA:protein ratios $(\mathbf{C})$ in various tissues (muscle, mantle, gill, gonads) of freshly captured (four bars on the left), long-term aquarium-maintained Adamussium colbecki (center four bars) and of freshly collected Aequipecten opercularis (four bars on the right). Data points are means $\pm \mathrm{SD}$ (freshly captured and long-term maintained Adamussium colbecki: $n=8$; Aequipecten opercularis: $n=6$ ). Only the same tissues were tested for significant differences. Values with the same letter are significantly different than those in Aequipecten opercularis (Fig. 3C) due to higher RNA concentrations (Fig. 3A) at similar protein contents (Fig. 3B). RNA contents were between twofold higher in gills to five-fold higher in muscle and gonads of freshly captured Adamussium colbecki than in Aequipecten opercularis. The high protein turnover in gills (Lyndon and Houlihan 1998) is reflected in a high RNA:protein ratio in both species when compared to muscle and mantle. Muscle naturally shows very low protein turnover rates associated with high protein retention. This was indicated by significantly higher protein concentrations in the muscle compared to gills at similar levels of RNA contents $\left(2.14 \pm 0.29 \mu \mathrm{g} \mathrm{mg}^{-1} \mathrm{FW}\right.$ in muscle; $2.30 \pm 0.13 \mu \mathrm{g} \mathrm{mg}^{-1} \mathrm{FW}$ in gill) of freshly captured Adamussium colbecki. This was even more evident in Aequipecten opercularis with significantly lower RNA contents in muscle $(0.43 \pm 0.03 \mu \mathrm{g}$ $\left.\mathrm{mg}^{-1} \mathrm{FW}\right)$ compared to gill tissue $\left(1.17 \pm 0.17 \mu \mathrm{g} \mathrm{m}^{-1}\right.$ FW) at significantly higher protein contents in muscle tissue. Both RNA and protein concentrations, and thus the RNA:protein ratio, were generally high in the gonads, compared to other tissues but varied substantially between and within species, probably due to variable reproduction stages. These variations were not visible in the other tissues.

Adamussium colbecki maintained for 6 months in the aquarium displayed a marked loss of RNA from the tissues despite continued feeding. Loss of RNA varied between $37 \%$ in gills to $56 \%$ in mantle compared to freshly captured Adamussium colbecki but RNA contents were still significantly higher than in the respective tissues of Aequipecten opercularis. Only in mantle and gill were decreasing RNA levels accompanied by a significant decrease in protein concentration. The decrease in RNA levels of the mantle tissue exceeded the loss of protein by $29 \%$ whereas the losses of RNA and protein in gill tissue were approximately the same. In accordance with a large reduction in RNA concentration and a lesser fall in protein content, the mean RNA:protein ratio was also reduced in most tissues indicating that Adamussium colbecki sustained starvation for some period. The high loss of protein in gill tissue is in line with the high protein turnover rates generally observed in gills.

\section{Discussion}

Capacity of protein synthesis in vitro

One of the prime obstacles to the study of in vitro protein synthesis capacity is the poor protein synthesis rate of cell-free systems obtained from assays conducted under non-optimized experimental conditions. The inefficiency of translation is due to gross deviations from physiological conditions, loss of compounds essential for protein synthesis during lysate preparation and/or insufficient high-energy phosphate levels in the translational system. All of these limitations were likely 
effective in the only existing study on a cell-free system prepared from an Antarctic ectotherm (Haschemeyer and Williams 1982). These authors prepared a cell-free protein synthesis system from liver of the Antarctic fish Trematomus bernacchii. They report an in vitro synthesis rate at $0{ }^{\circ} \mathrm{C}$ which was $1 / 1000$ th $(0.004 \%$ liver protein synthesized per day) of that observed in vivo (Smith and Haschemeyer 1980). Gill lysates from Adamussium colbecki measured at $0{ }^{\circ} \mathrm{C}$ were 4,100 -fold more active $(16.4 \%$ gill protein synthesized per day) and gill lysates from Aequipecten opercularis measured at $15^{\circ} \mathrm{C} 1,625-$ fold $(6.5 \%$ gill protein synthesized per day) when compared to the early determinations of protein synthesis rates in the in vitro system of Antarctic fish liver. The 1,000 fold lower in vitro than in vivo protein synthesis rates in liver of Trematomus bernacchii (Haschemeyer and Williams 1982) and the order of magnitude by which the pectinid cell-free systems exceed the activity of the "Trematomus" cell-free system corroborate the view, that due to improved methodology, values obtained in the present study reflect the full capacity of the protein synthesis machinery. Productivity was probably maximized by using crude, postmitochondrial lysates. The loss of low molecular weight compounds required for protein synthesis was minimized. Full capacity was exploited by the addition of high-energy phosphates (Storch and Pörtner 2003; Spirin et al. 1988; Kim and Swartz 2000). This accomplishment enabled us to determine the true protein synthesis and RNA translational capacities in cell-free translation systems of the two pectinid species.

Temperature dependence of protein synthesis capacities

The isolated translation machinery and its endogenous mRNA level is a snapshot of the cell, which mirrors the previous history of the in vivo protein synthesis system. Reversible changes in translational activity have been observed in vivo in response to growth factors, animal size, change in nutrient supply and various stress conditions (reviewed in Houlihan 1991). Freshly collected animals from both species were assumed to be in similar physiological condition because they were captured during summer, with abundant food in their respective habitats.

Adamussium colbecki very clearly possess protein synthesis machineries with higher RNA levels and RNA translational capacities than Aequipecten opercularis from warmer habitats. Furthermore, activation energies and $\mathrm{Q}_{10}$ values of protein synthesis were lower in Adamussium colbecki. These observations may reflect temperature compensation and indicate maximized protein synthesis capacities, despite low energy turnover rates in the Antarctic species. In spite of the long evolutionary isolation of Adamussium colbecki in a low and narrow temperature range, there was no thermal deterioration of protein synthesis capacity up to $15{ }^{\circ} \mathrm{C}$. Moreover, energetic costs of in vitro protein synthesis in
Adamussium colbecki and Aequipecten opercularis were found to be similar, at least for peptide elongation (Storch and Pörtner 2003). These patterns indicate that the principal characteristics and stoichiometries of protein synthesis (peptide bond formation, including tRNA acylation, initiation, elongation and termination) remained unchanged at significant lower levels of overall energy turnover which is due to stenothermal life in the permanent cold (Pörtner 2002).

Adaptation to low temperatures comprises increased RNA concentrations relative to protein content. This was found in all investigated tissues of Adamussium colbecki and seems to be a general phenomenon in cold-adapted ectotherms (Marsh et al. 2001; Fraser et al. 2002). However, translational activity was still found to be enhanced at low temperatures when corrected for different RNA contents. The high translational capacity of the ribosomes may result from functional optimization of the primary structures of core ribosome proteins and ribosome-associated proteins, such as initiation and elongation factors, as well as of the enzymes involved in protein synthesis. Examples for structural modifications indicative of thermal adaptation of the protein synthesis apparatus have been identified in several microorganisms (Ray et al. 1998; Thomas and Cavicchioli 2002). Increased activities of elongation factor EF-1 have been demonstrated in liver of Antarctic compared to temperate and tropical fish species (Haschemeyer and Williams 1982).

In vitro RNA translational capacity versus in vivo efficiency

Comparison of in vitro translational capacity of RNA with in vivo translational efficiency of RNA, requires careful definition of the two terms. The in vitro translational capacity reflects the topmost capacity of the ribosomes to synthesize protein indicated by the rate of in vitro protein synthesis per unit RNA. The RNA:protein ratio frequently determined in freshly collected tissues indirectly reflects this capacity in vivo but the extent to which this capacity is utilized, is indicated only by the rate of in vivo protein synthesis per unit RNA and is called translational efficiency ( $\mathrm{k}_{\mathrm{RNA}}$ in vivo; Waterlow et al.1978; Houlihan 1991).

Table 2 summarizes existing in vivo data on gill protein synthesis $\left(\mathrm{k}_{\mathrm{s}}\right), \mathrm{k}_{\mathrm{RNA}}$ in vivo and RNA content of different species in relation to ambient temperature and feeding conditions. The in vitro data obtained in both pectinids at their ambient temperatures were included for a preliminary comparison of the two terms. The in vitro protein synthesis capacities determined in both pectinids exceed by far all values of in vivo efficiency determined in gill tissues of other ectotherms inhabiting various temperature environments. This global comparison suggests that actual in vivo protein synthesis rates remain far below capacity. Certainly, for a confirmation of this conclusion, in vivo protein synthesis should be measured in the two pectinids. 
Table 2 Fractional rates of protein synthesis $\left(k_{s}\right)$ in vivo, translational efficiency ( $k_{R N A}$ in vivo $)$ and RNA content in gills of invertebrates and fish species (fasted and fed) adapted to different ambient temperatures. For a preliminary comparison, the in vitro data ( $k_{R N A}$ in vitro translational capacity) obtained in the present study are included and demonstrate excess capacity over in vivo rates. $\mathrm{k}_{\mathrm{s}}$ fractional protein synthesis rate $\left(\%\right.$ protein synthesized day $\left.{ }^{-1}\right)$, $\mathrm{k}_{\mathrm{RNA}}$ in vivo and in vitro ( $\mathrm{mg}$ protein synthesized $\mathrm{mg} \mathrm{RNA}^{-1}$ day $^{-1}$ ), RNA (mg/gFW); FW fresh water. Numbers in parenthesesare used as data point labels in Fig. 4

\begin{tabular}{|c|c|c|c|c|c|}
\hline Species & Temperature $\left({ }^{\circ} \mathrm{C}\right)$ & Gill $\mathrm{k}_{\mathrm{s}}$ & $\mathrm{k}_{\mathrm{RNA}}$ & RNA & Reference \\
\hline $\begin{array}{l}\text { Antarctic invertebrates } \\
\text { Adamussium colbecki aquarium maintained } \\
\text { Adamussium colbecki fed }\end{array}$ & $\begin{array}{l}0 \\
-\end{array}$ & $\begin{array}{l}7.3 \\
16.4\end{array}$ & $\begin{array}{l}2.3 \\
5.8\end{array}$ & $\begin{array}{l}1.56 \\
2.30\end{array}$ & $\begin{array}{l}\text { This paper (in vitro) } \\
-\end{array}$ \\
\hline $\begin{array}{l}\text { Antarctic fish } \\
\text { Trematomus bernacchii fasted } \\
\text { Trematomus bernacchii fed } \\
\text { Trematomus hansoni fasted } \\
\text { Trematomus hansoni fed } \\
\text { Trematomus newnesi } \\
\text { Gymnodraco acuticeps } \\
\text { Notothenia corriceps fasted } \\
\text { Notothenia corriceps fed } \\
\text { Chaenocephalus aceratus (Icefish) }\end{array}$ & $\begin{array}{l}-1.5 \\
- \\
-1.5 \\
- \\
-1.5 \\
-1.5 \\
2 \\
- \\
2\end{array}$ & $\begin{array}{l}3.9 \\
5.3 \\
2.2 \\
3.2 \\
1.5 \\
1.3 \\
2.9 \\
1.6 \\
0.85\end{array}$ & $\begin{array}{l}- \\
- \\
0.6 \\
1.3 \\
- \\
- \\
- \\
- \\
-\end{array}$ & $\begin{array}{l}- \\
- \\
1.4 \\
1.6 \\
- \\
- \\
- \\
- \\
-\end{array}$ & $\begin{array}{l}\text { Smith and Haschemeyer (1980) (1) } \\
- \\
\text { Smith and Haschemeyer (1980) (2) } \\
- \\
\text { Smith and Haschemeyer (1980) (3) } \\
\text { Smith and Haschemeyer (1980) (4) } \\
\text { Haschemeyer (1983)(5) } \\
\text { - Haschemeyer (1983) (6) }\end{array}$ \\
\hline $\begin{array}{l}\text { Temperate invertebrates } \\
\text { Aequipecten opercularis fed } \\
\text { Carcinus maenas fasted } \\
\text { Carcinus maenas fed } \\
\text { Octopus vulgaris fasted } \\
\text { Octopus vulgaris fed }\end{array}$ & $\begin{array}{l}15 \\
15 \\
- \\
22 \\
-\end{array}$ & $\begin{array}{l}6.5 \\
2.4 \\
4.8 \\
2.96 \\
11.26\end{array}$ & $\begin{array}{l}3.7 \\
0.58 \\
1.58 \\
0.61 \\
1.19\end{array}$ & $\begin{array}{l}1.17 \\
- \\
- \\
- \\
-\end{array}$ & $\begin{array}{l}\text { This paper (in vitro) } \\
\text { Houlihan et al. (1990b)(7) } \\
\text { Houlihan et al. (1990a)(8) } \\
\text { - }\end{array}$ \\
\hline $\begin{array}{l}\text { Temperate fish } \\
\text { Salmo gairdneri (FW) } \\
\text { Gadus morhua fed } \\
\text { Gadus morhua fed } \\
\text { Oncorhynchus mykiss fasted } \\
\text { Oncorhynchus mykiss fed } \\
\text { Sufflamen verres } \\
\text { (Triggerfish) }\end{array}$ & $\begin{array}{l}12 \\
5 \\
15 \\
15 \\
- \\
26 \\
30\end{array}$ & $\begin{array}{l}9.1 \\
7.8 \\
8.8 \\
6.44 \\
13.96 \\
15 \\
14\end{array}$ & $\begin{array}{l}- \\
1.3 \\
1.5 \\
1.63 \\
2.13 \\
- \\
-\end{array}$ & $\begin{array}{l}- \\
5.0 \\
3.8 \\
- \\
- \\
- \\
-\end{array}$ & $\begin{array}{l}\text { Houlihan et al. (1986)(9) } \\
\text { Foster et al. (1992) (10) } \\
\text { McMillan and Houlihan (1989) (1988) (11) } \\
- \\
\text { Haschemeyer et al. (1979) (12) } \\
-\end{array}$ \\
\hline
\end{tabular}

In general, amino acid availability and the competition for cellular energy in the form of ATP may play a major role in understanding why protein synthesis in vivo remains below capacity. Furthermore, several studies suggest that with energy being available, initiation is the rate-limiting step and the most common site for global control of translation (Hofmann and Hand 1994). Control at initiation is most often mediated by the phosphorylation/dephosphorylation of initiation factors, as seen, for example, in mammalian cells (Hershey 1991). Furthermore, the regulation of the GTP:GDP ratio by adenylate levels is a sensitive control parameter for ternary complex (eIF2-GTP-Met-tRNAi) formation in eukaryotic cells (Walton and Gill 1976).

In vitro protein synthesis in gills of aquarium-maintained Adamussium colbecki

The effect of nutrition or season or both is also relevant when studying protein synthesis in ectotherms. This may be especially true for animals from the cold Antarctic where food availability for some species may be highly seasonal and limited to the austral summer. Adamussium colbecki, maintained in the aquarium for 6 months, displayed indications of limited food supply despite regular presence of food. These (aquarium) animals were sampled during their austral wintertime and showed metabolic depression by up to $30 \%$, indicative of food limitation or a winter status of these animals (Heilmayer and Brey 2003). The reduced protein synthesis rates and translational capacity in vitro in the gills of these Adamussium colbecki specimens, mirrors such a significant change in the nutritional condition and metabolic rate of these animals. Low protein synthesis rate is reflected in a loss of protein synthesis machinery, indicated by reduced RNA levels and by a decrease in the amount of protein synthesized per milligram of RNA, thus translational capacity. Interestingly, the temperature dependence of protein synthesis was reduced under these conditions, indicated by a lower $\mathrm{Q}_{10}$. This finding suggests a lower activation enthalpy and thus, less cold induced restriction of protein synthesis.

According to Fig. 4, this may be a general pattern among ectotherms. A reduction in food consumption has been shown to decrease in vivo protein synthesis rates and RNA translational efficiency in the gills of various ectotherms (Table 2) and the effect of temperature seems to be reduced in fasting animals (Fig. 4). An animal deprived of food looses weight rapidly but the response is quite variable in individual tissues and can be controlled by the animal (reviewed by Houlihan 1991). The gills in long-term maintained Adamussium colbecki sustained the highest protein loss whereas 

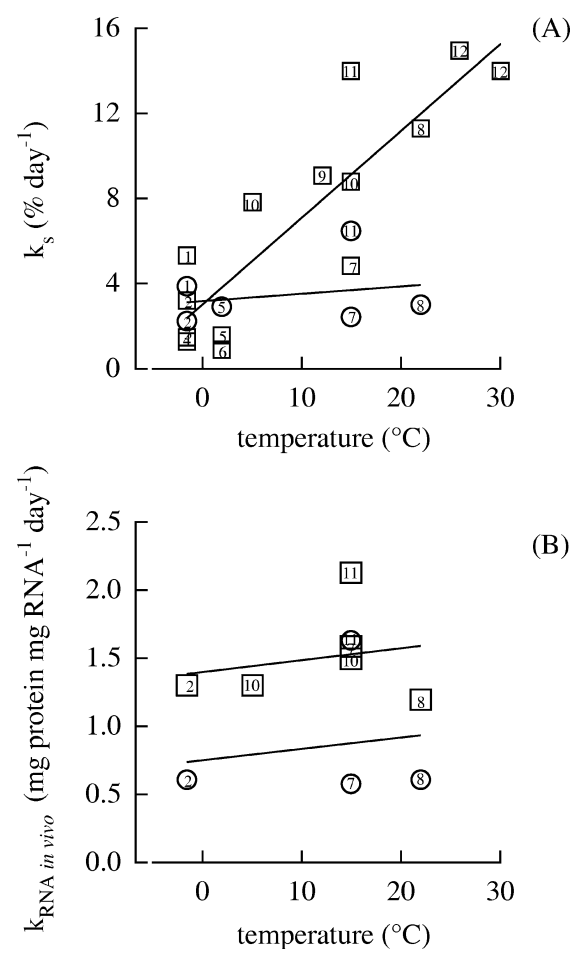

Fig. 4A-B Effect of temperature on fractional protein synthesis rates $\left(k_{s}\right)(\mathbf{A})$ and on translational efficiencies $\left(k_{R N A}\right.$ in vivo $)(\mathbf{B})$ measured in vivo in gills of various fed (squares) and fasted (circles) ectotherms. For literature sources of plotted data, see Table 2

muscle protein levels remained the same. It is noteworthy that gills are characterized by very low protein retention efficiency, whereas muscles display very high efficiencies of protein retention (Houlihan et al. 1989; Houlihan 1991; Lyndon and Houlihan 1998). This in turn indicates significant differences in protein stability between various tissues, which seem to be high in muscle but low in gills of cold-adapted Adamussium colbecki. The loss of protein synthesis apparatus in the gills of aquarium-maintained Adamussium colbecki, which goes hand in hand with a loss of protein content, suggests higher degradation than synthesis rates. Similarly, protein degradation rates in eurythermal salmon were in excess of synthesis rates after 4 months starvation, leading to protein loss in the gills, ventricle, stomach but also red and white muscle (Houlihan 1991). Fraser et al. (2002) observed a parallel reduction of body mass, RNA:protein ratios and protein synthesis rates in the Antarctic limpet Nacella concinna during the austral winter.

\section{Summary and conclusions}

The patterns observed in the two pectinid species suggest that limitations of protein synthesis capacities in the cold may be compensated for by both enhanced RNA levels and enhanced RNA translational capacities. This may be particularly important in tissues with high protein turnover rates and low protein retention efficiencies, such as gills. The increased RNA content in the cold may be a result of low RNA turnover rates, with the advantage of enhanced cost-efficiency. Seasonality or variable food supply of the animal seem to outrank temperature effects on protein synthesis capacities and actual in vivo rates, a conclusion supported by findings in Adamussium colbecki after long-term aquarium maintenance and by the few in vivo data found in the literature and summarized in Table 2 and Fig. 4.

Even though between-species comparisons like in Fig. 4 have to be treated with caution, a few general patterns arise:

1. In vivo protein synthesis rates in gill tissues of fed fish or invertebrates increase with increasing ambient temperatures, whereas the translational efficiency of RNA remains more or less unchanged. This is in line with the observation of temperature-compensated RNA translational capacities as outlined above.

2. The temperature dependence of in vivo protein synthesis rates in starved fish or invertebrates is less pronounced and translational efficiency is markedly reduced when compared to fed conspecifics (Fig. 4). Accordingly, the value of $\mathrm{k}_{\mathrm{RNA}}$ is sensitive to the nutritional state of an animal (Millward et al. 1973).

Consequently, increased food demands at higher temperatures must be taken into consideration when studying protein synthesis at different temperatures and latitudes (Houlihan 1991).

As a corollary, current evidence indicates that coldcompensated protein synthesis capacities may not be fully exploited in vivo in the cold, but support similar maximum summer growth rates in Antarctic and temperate regions (Brey and Clarke 1993; Clarke and Leakey 1996; Peck 2002) when enough food and, thus, energy is available. Enhanced capacities of the protein synthesis apparatus in the cold resemble high enzyme capacities of aerobic metabolism, which are cold compensated too, despite reduced standard and maximum metabolic rates. Such excess capacities in metabolic and protein synthesis functions may be relevant for rapid adjustment of metabolic and functional equilibria and for full metabolic flexibility in response to external and internal stimuli in the permanent cold. The extremely high capacity of the protein synthesis system in the Antarctic scallop strongly supports these conclusions; however, any generalized statement on the level of cold compensation in protein synthesis capacity in Antarctic stenotherms requires further comparative study of cold- versus warm-adapted ectotherms with similar lifestyles.

Acknowledgements We are grateful to the staff of the "Station Biologique de Roscoff" for providing Aequipecten opercularis. The work on Antarctic scallops was carried out as part of the Italian research programme "Progetto Nazionale Ricerche in Antartide" (PNRA). We would like to thank Riccardo Cattaneo Vietti and Chiara Chiantore for the invitation to their beautiful Italian base "Terra Nova Bay". The experiments conducted in this study comply with the current laws of Germany. 


\section{References}

Ashford AJ, Pain VM (1986) Effect of diabetes on the rates of synthesis and degradation of ribosomes in rat muscle and liver in vivo. J Biol Chem 261:4059-4065

Bailey DM, Peck LS, Bock C, Pörtner HO (2003) High energy phosphate metabolism during exercise and recovery in temperate and Antarctic scallops-an in vivo 31P-NMR study. Physiol Biochem Zool (In press)

Brey T, Clarke A (1993) Population dynamics of marine benthic invertebrates in Antarctic and subantarctic environments: are there unique adaptations. Ant Sci 5:253-266

Canapa A, Barucca M, Marinelli A, Olmo E (2000) Molecular data from the 16S rRNA gene for the phylogeny of Pectinidae (Mollusca: Bivalvia). J Mol Evol 50:93-97

Clarke A, Leakey RJG (1996) The seasonal cycle of phytoplankton, macronutrients, and the microbial community in a nearshore Antarctic marine ecosystem. Limnol Oceanogr 41:1281-1294

Foster AR, Houlihan DF, Hall SJ, Burren LJ (1992) The effects of temperature acclimation on protein synthesis rates and nucleic acid content of juvenile cod (Gadus morhua L.). Can J Zool 70:2095-2102

Fraser KP, Clarke A, Peck LS (2002) Low-temperature protein metabolism: seasonal changes in protein synthesis and RNA dynamics in the Antarctic limpet Nacella concinna Strebel (1908). J Exp Biol 205:3077-3086

Haschemeyer AE (1983) A comparative study of protein synthesis in nototheniids and icefish at Palmer Station, Antarctica. Comp Biochem Physiol B 76:541-543

Haschemeyer AE, Persell R, Smith MA (1979) Effect of temperature on protein synthesis in fish of the Galapagos and Perlas Islands. Comp Biochem Physiol B 64:91-95

Haschemeyer AEV, Williams RC Jr (1982) Temperature dependency of cell-free protein synthetic systems from Antarctic fish. Mar Biol Lett 3:81-88

Hawkins AJS (1991) Protein turnover: a functional appraisal. Funct Ecol 5:222-233

Heilmayer O, Brey T (2003) Saving by freezing? Metabolic rates of Adamussium colbecki in a latitudinal context. Mar Biol 143:477-484

Heilmayer O, Brey T, Storch D, Mackensen A, Arntz WE (2004) Population dynamics and metabolism of Aequipecten opercularis (L.) from the western English Channel (Roscoff, France). Neth J Sea Res (In press)

Hershey JWB (1991) Translational control in mammalian cells. Annu Rev Biochem 60:717-755

Hofmann GE, Hand SC (1994) Global arrest of translation during invertebrate quiescence. Proc Natl Acad Sci USA 91:8492-8496

Houlihan DF (1991) Protein turnover in ectotherms and its relationships to energetics. In: Gilles R (ed) Advances in comparative and environmental physiology, vol 7. Springer, Berlin Heidelberg New York, pp 1-43

Houlihan DF, McMillan DN, Laurent P (1986) Growth rates, protein synthesis, and protein degradation rates in rainbow trout: effects of body size. Physiol Zool 59:482-493

Houlihan DF, Hall SJ, Gray C (1989) Effects of ration on protein turnover in cod. Aquaculture 79:103-110

Houlihan DF, McMillan DN, Agnisola C, Trara Genoino I, Foti L (1990a) Protein synthesis and growth in Octopus vulgaris. Mar Biol 106:251-259

Houlihan DF, Waring CP, Mathers E, Gray C (1990b) Protein synthesis and oxygen consumption of the shore crab Carcinus maenas after a meal. Physiol Zool 63:735-756
Kim DM, Swartz JR (2000) Prolonging cell-free protein synthesis by selective reagent additions. Biotechnol Prog 16:385-390

Lied E, Lie O, Lambertsen G (1985) Nutritional evaluation in fish by measurement of in vitro protein synthesis in white trunk muscle tissue. In: Conwey CB, Mackie AM, Bell JG (eds) Nutrition and feeding in fish. Academic Press, London, pp 169176

Lyndon AR, Houlihan DF (1998) Gill protein turnover: costs of adaptation. Comp Biochem Physiol A 119:27-34

Marsh AG, Maxson RE Jr, Manahan DT (2001) High macromolecular synthesis with low metabolic cost in Antarctic sea urchin embryos. Science 291:1950-1952

McMillan DN, Houlihan DF (1988) The effect of refeeding on tissue protein synthesis in rainbow trout. Physiol Zool 61:429441

McMillan DN, Houlihan DF (1989) Short-term responses of protein synthesis to re-feeding in rainbow trout. Aquaculture 79:37-46

Millward DJ, Garlick PJ, James WP, Nnanyelugo DO, Ryatt JS (1973) Relationship between protein synthesis and RNA content in skeletal muscle. Nature 241:204-205

Munro HN, Fleck A (1966) Recent developments in the measurement of nucleic acids in biological materials. A supplementary review. Analyst 91:78-88

Peck LS (2002) Ecophysiology of Antarctic marine ectotherms: limits to life. Polar Biol 25:31-40

Pörtner HO (2002) Physiological basis of temperature-dependent biogeography: trade-offs in muscle design and performance in polar ectotherms. J Exp Biol 205:2217-2230

Ray KM, Kumar GS, Janiyani K, Kannan K, Jagtap P, Basu MK, Shivaji S (1998) Adaptation to low temperature and regulation of gene expression in antartic psychrotrophic bacteria. J Biosci 23:423-435

Robertson RF, El-Haj AJ, Clarke A, Peck LS, Taylor EW (2001) The effects of temperature on metabolic rate and protein synthesis following a meal in the isopod Glyptonotus antarcticus Eights (1852). Polar Biol 24:677-686

Segel LA (1976) Incorporation of receptor kinetics into a model for bacterial chemotaxis. J Theor Biol 57:23-42

Smith MAK, Haschemeyer AEV (1980) Protein metabolism and cold adaptation in Antarctic fishes. Physiol Zool 53:373-382

Spirin AS, Baranov VI, Ryabova LA, Ovodov SY, Alakhov YB (1988) A continuous cell-free translation system capable of producing polypeptides in high yield. Science 242:1162-1164

Storch D, Pörtner HO (2003) The protein synthesis machinery operates at the same expense in eurythermal and cold stenothermal pectinids. Physiol Biochem Zool 76:76:28-40

Thomas T, Cavicchioli R (2002) Cold adaptation of archaeal elongation factor $2(\mathrm{EF}-2)$ proteins. Curr Protein Pept Sci 3:223-230

Walton GM, Gill GN (1976) Preferential regulation of protein synthesis initiation complex formation by purine nucleotides. Biochim Biophys Acta 447:11-19

Waterlow JC, Garlick PJ, Millward DJ (1978) The relationship between protein synthesis and cell growth. In: Waterlow JC, Garlick PJ, Millward DJ (eds) Protein turnover in mammalian tissues and in the whole body. Elsevier, Amsterdam, pp 538557

Whiteley NM, Taylor EW, Haj AJ el (1996) A comparison of the metabolic cost of protein synthesis in stenothermal and eurythermal isopod crustaceans. Am J Physiol 271:R1295-R1303

Wollenberger AO, Ristau O, Schoffa G (1960) Eine einfache Technik der extrem schnellen Abkühlung grosser Gewebestücke. Eur J Physiol 270:399-412 